\title{
PENINGKATAN KESEJAHTERAAN MASYARAKAT DENGAN KUBE DI DESA KENDUNG SURABAYA
}

\author{
Yuli Ermawati ${ }^{1}$, Suprayoga ${ }^{2,}$ Antoni $^{3}$ \\ ${ }^{1}$ Universitas Wijaya Putra \\ ${ }^{2}$ Universitas Wijaya Putra \\ ${ }^{3}$ Universitas Wijaya Putra \\ yuliermawati@uwp.ac.id, suprayoga@uwp.ac.id, antoni@uwp.ac.id
}

\begin{abstract}
Abstrak
Desa Kendung terkenal dengan sebutan "Kampung Semanggi" dikarenakan mayoritas pedagang semanggi baik mentah maupun olahan semanggi berasal dari daerah ini. Mulai dari petani semanggi, pengepul daun semanggi, sampai pedagang pecel semanggi dan olahan semanggi lainnya. Adapun mitra yang menjadi mitra Program Pemberdayaan Masyarakat (PPM) ini adalah 10 pedagang semanggi di Kendung RT 07 RW III. Kondisi kegiatan usaha mereka ada yang sudah mulai mengalami peningkatan, ada yang masih diam di tempat, dan ada yang mengalami penurunan. Pokok permasalahan yang dihadapi oleh mitra adalah belum adanya manajemen usaha yang tertata rapi dan akses keluar baik pendanaan maupun pemasaran yang masih konvensional serta tidak adanya sarana yang bisa memfasilitasi mereka untuk membentuk komunitas. Tujuan dari pemberdayaan ini adalah menggali potensi pedagang semanggi di Kendung dan menemukan strategi yang tepat untuk memberikan pelatihan, membentuk Kelompok Usaha Bersama di kalangan pedagang semanggi dan mengawal mereka untuk mendapatkan pemberdayaan lebih lanjut dari pemerintah.

Metode yang digunakan adalah pendampingan 1) Membuat analisis SWOT untuk menggali potensi pedagang semanggi di desa Kendung, 2)Untuk aspek Manajemen Usaha (Tata kelola, keuangan, pemasaran), tim Abmas memberikan pelatihan manajemen usaha, keuangan, maupun pemasaran online, 3)Untuk aspek Sosial Budaya, Tim menginspirasi mitra untuk membentuk tim Kelompok Usaha Bersama (KUBE) dan mengawal proposal pengajuan pembentukan KUBE ke Kecamatan dan sampai pada Dinas Pemerintah terkait untuk mendapatkan pemberdayaan lebih lanjut dari pemerintah. Hasil yang diperoleh adalah terlaksananya kegiatan pelatihan, munculnya berbagai varian produk olahan semanggi, terbentuknya Warung Online "Omah Semanggi”, dan terbentuknya KUBE “Semanggi Bersemi” untuk dilanjutkan ke Dinas Pemerintah terkait.
\end{abstract}

Kata Kunci : Kelompok Usaha Bersama, Pedagang Semanggi 


\section{PENDAHULUAN}

Desa Kendung terkenal dengan sebutan "Kampung Semanggi" dikarenakan mayoritas pedagang semanggi baik mentah maupun olahan semanggi berasal dari daerah ini. Mulai dari petani semanggi, pengepul daun semanggi, sampai pedagang pecel semanggi dan olahan semanggi lainnya. Semanggi adalah sekelompok paku air dari marga Marsilea yang di Indonesia mudah ditemukan di pematang sawah atau tepi saluran irigasi. Semanggi tumbuh di kawasan yang tergenang air tetapi harus mendapat pasokan sinar matahari yang cukup.

Berdasarkan hasil uji penelitian oleh seorang ahli, didapati bahwa prosentase komposisi zat kimia yang ada dalam daun dan tangkai semanggi terdiri atas (1) air 89,02\%, (2) abu 2,70 $\%$ (3) protein 4,35\% (4) lemak 0,27\% (5) serat kasar 2,28\% (faktualnews.co.id). Manfaat daun semanggi antara lain mengandung zat fitoestrogen dari tumbuhan yang berkhasiat untuk mencegah osteoporosis, digunakan dalam penyembuhan bagi penderita sakit pengecilan hati, mengobati infeksi saluran kencing, mengobati amandel dan mengobati batuk dan sesak nafas.

Lebih dari 100 pedagang semanggi berasal dari Kampung Semanggi dan memasarkan dagangannya tidak hanya ke seluruh Surabaya, bahkan ada yang sampai ke luar kota. Mereka cenderung melakukan kegiatan secara sporadis. Perkembangan usaha mereka juga tidak merata karena walaupun tempat tinggal mereka berdekatan, namun mereka tidak memiliki fasilitas atau sarana untuk berkumpul dan berbagi ilmu/pengalaman.

Diantara para pedagang semanggi ada yang sudah mempunyai stand/tempat tetap untuk berdagang, dan ada juga yang berkeliling dengan membawa rinjing/bakul. Ada yang sudah menjalankan usaha dengan stabil dan memasarkan produknya secara online melalui media wa, namun ada juga yang hanya berjualan seminggu sekali karena sepinya pasar semenjak pandemi covid'19. Usaha mereka rata-rata masih tergolong konvensional dan belum memiliki manajemen usaha yang rapi. Masih belum banyak kegiatan atau pemberdayaan dari pemerintah yang menyentuh dan memberikan arahan kepada mereka untuk meningkatkan usaha mereka.

Untuk itu perlu adanya suatu bentuk pemberdayaan yang dapat memotivasi, menggabungkan, dan meningkatkan kompetensi mereka demi kesejahteraan bersama. Salah satu caranya adalah dengan perintisan pembentukan KUBE (Kelompok Usaha Bersama). KUBE sebagai upaya penanggulangan kemiskinan dilaksanakan dengan strategi penguatan kelompok, diharapkan dapat memberikan solusi terhadap masalah yang dihadapi mitra.

\section{METODE}

Dalam upaya peningkatan kesejahteraan pedagang semanggi, tim fasilitator merintis pembentukan KUBE yang sebelumnya belum ada di Desa Kendung. Metode yang digunakan yaitu dengan sebagai berikut (1)melakukan analisis SWOT untuk menggali potensi pedagang semanggi, (2)memotivasi dan menginspirasi pedagang semanggi untuk membentuk tim Kelompok Usaha Bersama (KUBE), (3)memberikan pelatihan dan pemberdayaan awal baik dari segi manajemen packaging, manajemen keuangan, diversifikasi produk maupun pemasaran online (4)Setelah semua proses pemberdayaan dilakukan, tim fasilitator akan mengawal proposal pembentukan KUBE ke Kecamatan dan sampai pada Dinas Pemerintah terkait dan memantau sampai proses KUBE selesai dan proses pemberdayaan beralih ke Pemerintah

Untuk mengevaluasi pelaksanaan program keberlanjutan program di lapangan setelah selesai dilakukan, tim membuat evaluasi dan penilaian yang dipantau setiap dua bulan sekali 


\section{HASIL DAN PEMBAHASAN}

Hasil kegiatan adalah tim fasilitator telah memetakan potensi yang dimiliki oleh pedagang semanggi di desa Kendung Kampung Semanggi, memberikan beberapa pelatihan dan membentuk KUBE (Kelompok Usaha Bersama).

\section{Analisis SWOT}

Tim fasilitator memetakan potensi yang dimiliki oleh pedagang semanggi di Desa Kendung melalui wawancara dan pendekatan kualitatif kepada mereka. Adapun hasil tersebut sebagai berikut :

\begin{tabular}{|l|l|}
\hline Strengths & - Semanggi mempunyai \\
(Kekuatan) & banyak manfaat \\
& - Semanggi memiliki banyak \\
& pelanggan/konsumen \\
& - Semanggi bisa diolah \\
& menjadi beraneka olahan \\
& makanan \\
& - Jumlah pedagang \\
& semanggi banyak \\
& - Dukungan penuh dari \\
& pengurus RT dan RW \\
\hline Weaknesses & - Belum ada standarisasi \\
(Kelemahan) & olahan semanggi \\
& - Olahan produk Semanggi \\
& masih terbatas \\
& - Pemasaran semanggi \\
& masih minim \\
& - Kegiatan pedagang \\
& semanggi masih sporadis \\
& (tersebar) \\
\hline Opportunities & - Adanya investor asing yang \\
& memberikan sarana hibah \\
& untuk desa \\
& - Semangat ingin maju yang \\
& masih tinggi dan mudah \\
& diinspirasi \\
& - Semanggi mempunyai \\
& digali \\
& - Semanggi bisa diolah \\
\hline
\end{tabular}

\begin{tabular}{|l|l|}
\hline & $\begin{array}{l}\text { menjadi berbagai olahan } \\
\text { makanan }\end{array}$ \\
\hline Threats & - Jumlah tanaman Semanggi \\
(Ancaman) & terbatas \\
& - Lahan penanaman \\
& Semanggi terbatas \\
\hline
\end{tabular}

Dari hasil identifikasi SWOT diatas, maka tim fasilitator menganalisa strategi yang tepat untuk meningkatkan kesejahteraan pedagang semanggi melalui KUBE. Adapaun strategi yang didapat antara lain; 1) Meningkatkan budidaya tanaman semanggi di lahan sempit, 2)Mengidentifikasi titik pengepul tanaman semanggi, 3)Membuat standardisasi pengolahan semanggi, 4)Mengolah semanggi menjadi berbagai olahan makanan (diversifikasi), 5)Meningkatkan target pemasaran olahan semanggi, 6)Melakukan sosialisasi standar packaging unik dan praktis, 7)Membentuk kelompok usaha di kalangan pedagang semanggi, 8)Membuat sentra pedagang semanggi yang berpotensi menjadi kawasan wisata

\section{Pelatihan(manajemen packaging, manajemen keuangan, diversifikasi produk maupun pemasaran online)}

Tim Fasilitator memberikan beberapa pelatihan untuk pedagang semanggi baik pengepul semanggi mentah maupun semanggi olahan. Pelatihan yang diberikan antara lain pelatihan manajemen packaging, manajemen keuangan, diversifikasi olahan semanggi baru dan pemasaran online. Selain itu juga memberikan Hypnoselling untuk memotivasi pedagang semanggi agar lebih semangat dan percaya diri dalam mengembangkan usahanya.
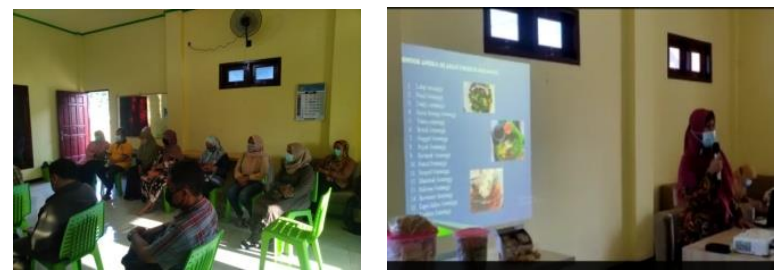

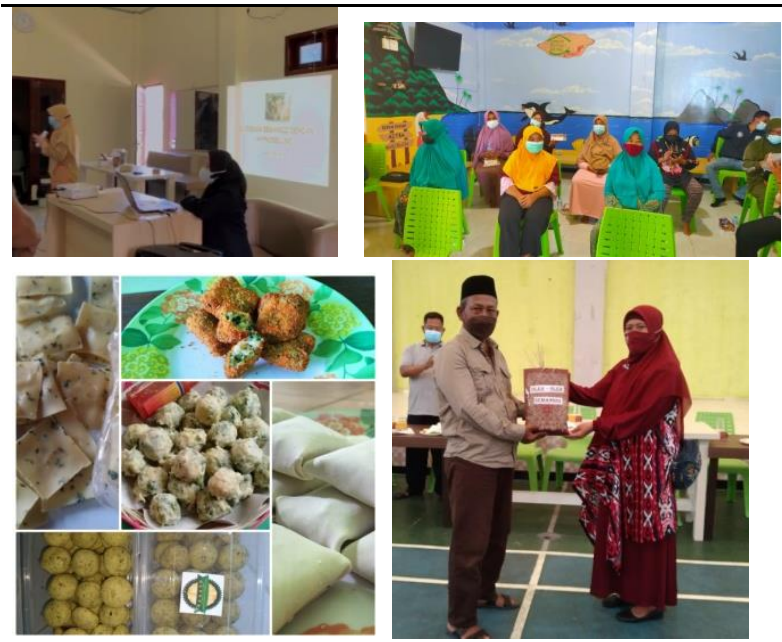

Gambar pelatihan untuk pedagang semanggi

\section{KESIMPULAN}

Untuk menemukan strategi yang tepat dalam meningkatkan kesejahteraan pedagang semanggi melalui KUBE, maka tim fasilitator melakukan analisis SWOT. Setelah ditemukan strategi yang tepat berdasarkan perhitungan analisis SWOT, maka tim melakukan beberapa pelatihan dan mengevaluasi hasil Pelatihan setiap dua bulan sekali. Implikasi yang terjadi diantara pedagang semanggi telah terbentu $2 \mathrm{KUBE}$ yang terdiri dari 10 orang di masing-masing kelompok. Pedagang semanggi juga telah menerima pelatihan seperti manajemen packaging, manajemen keuangan, diversifikasi produk dan bersama-sama memasarkan usaha mereka secara online melalui wadah usaha yang juga disinergikan dengan sosmed karang taruna kampung semanggi.

\section{UCAPAN TERIMAKASIH}

Ucapan terimakasih disampaikan kepada Universitas Wijaya Putra yang telah memfasilitasi Kegiatan pembentukan KUBE pedagang semanggi dan semua pedagang semanggi di kampung semanggi yang telah memberikan kontribusi dalam pelaksanaan kegiatan.

\section{REFERENSI}

Ahmad,Faizal.dan E.Rahayu. 2018. Model Kemitraan dalam Pemberdayaan Usaha Mikro Pedesaan. Jurnal Ilmu Kesejahteraan Sosial 19(2):145-158

Departemen Sosial RI, Direktorat Jendral Pemberdayaan Sosial, Pemberdayaan Fakir Miskin 2006

Budiani Ni Wayan, 2007, Efektivitas Program Penanggulangan Pengangguran Karang Taruna "Eka Taruna Bhakti" Desa Sumerta Kelod Kecamatan Denpasar Timur Kota Denpasar, (Online), Vol. 2 No. 1

Rohmah,Fathatur.T.Domai,Sukanto. 2019. Strategi Pemerintah Daerah Dalam Pemberdayaan Usaha Mikro Kecil Menengah Olahan Mangga (Studi Kasus Sentra Olahan Mangga Desa Banjarsari, Kecamatan Sumberasih, Kabupaten Probolinggo. Jurnal Administrasi Publik 3(12):2040-2044

Qur'an,Amanah Aida. 2017. Pemberdayaan Masyarakat pada Kelompok Usaha Bersama (Studi pada KUBE Kaligondang Purbalingga Jawa Tengah). Tesis. IAIN Purwokerto 